
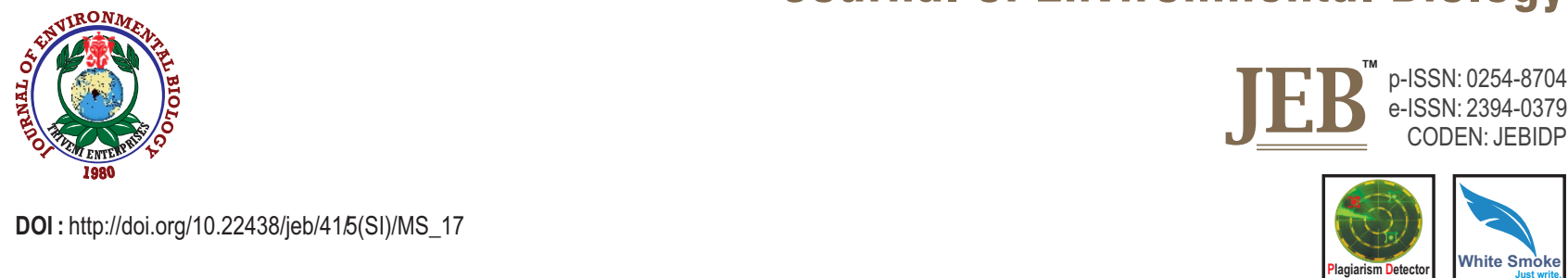

\title{
Effect of different frozen fresh diets to broodstock growth, reproductive performance and larvae of cleaner shrimp, Lysmata amboinensis
}

\author{
W.N.A. Omar ${ }^{1,2}$, A. Arshad ${ }^{1,2 *}$, S.M.N. Amin ${ }^{2,3}$ and A. Christianus ${ }^{2}$ \\ ${ }^{1}$ International Institute of Aquaculture and Aquatic Sciences (I-AQUAS), Universiti Putra Malaysia, Jalan Kemang 6, Batu 7 Teluk Kemang, 71050 \\ Port Dickson, Negeri Sembilan, Malaysia \\ ${ }^{2}$ Department of Aquaculture, Faculty of Agriculture, Universiti Putra Malaysia, Serdang, Selangor 43400, Malaysia \\ ${ }^{3}$ FAO World Fisheries University, Pukyong National University, Nam-gu, Busan-48547, South Korea \\ *Corresponding Author Email : azizarshad@upm.edu.my
}

\section{Abstract}

Aim: To evaluate the effects of different frozen fresh diets of frozen mussel, squid, polychaetes and the mixture of all feeds) to $L$. amboinensis broodstock.

Methodology : Four diets, comprised of squid (Loligo sp.), mussel (Perna viridis), polychaetes (Marphys amoribidii) separately, as well as the mixture of all four separately were fed to $L$. amboinensis brood stocks. The results were evaluated based on the biochemical compositions (proximate analyses and fatty acid composition of feed), broodstock conditions (survival and growth), reproductive performances (egg cover under abdomen (\%), egg fecundity and viable fecundity) and larval quality (morphometric measurement).

Results : Mussel diet produced the highest number of larvae, followed by polychaetes and mix diets. On the contrary, broodstock nourished with squid diet had suffered a heavy loss of eggs throughout the incubation period, with lowered larvae production $(p<0.05)$. The results demonstrated a good relationship between the MUFA content in the diet from the egg produced from this cleaner shrimp whereas the level of 22: $6 \mathrm{n}-3(\mathrm{DHA})$ in the diet exhibited close relation with egg retention throughout the incubation period.

Interpretation: Broodstock diet influences the egg cover during incubation, egg fecundity, viable fecundity and output in terms of $L$. amboinensis larval morphometric. MUFA has several potential functions in the embryonic development process related to fecundity, while DHA has different functions in early embryogenesis, where it is associated with egg hatchability and larval morphometric of $L$. amboinensis.

Key words : Broodstock, Lysmata amboinensis, Reproductive performance, Shrimp

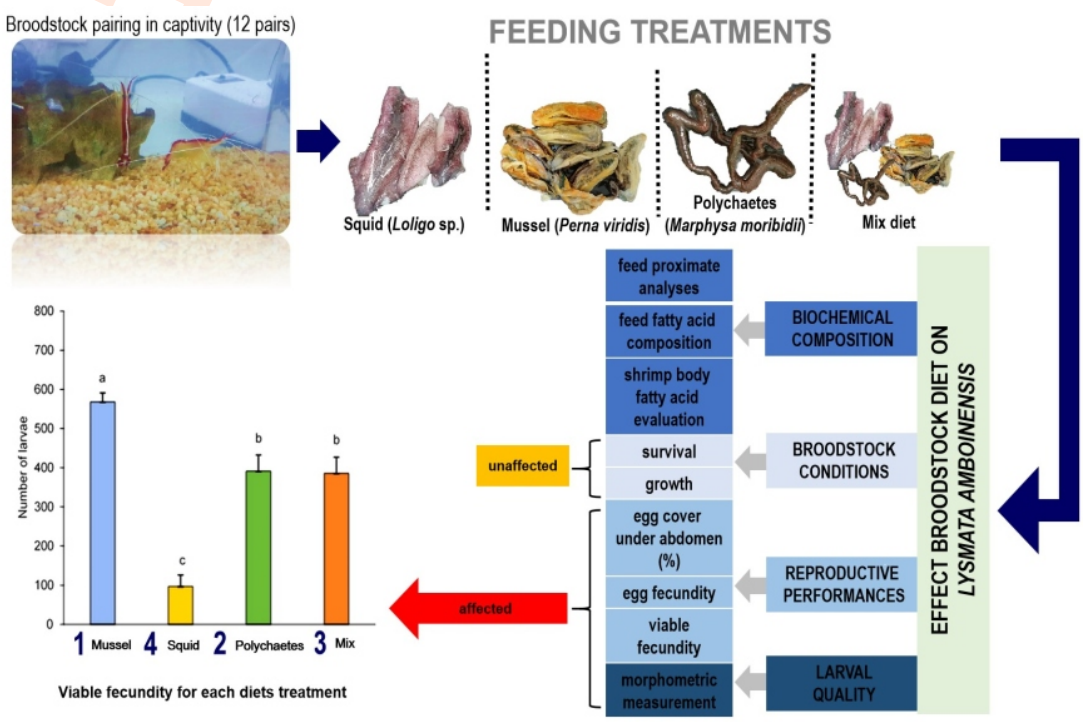

How to cite : Omar, W.N.A., A. Arshad, S.M.N. Amin and A. Christianus: Effect of different frozen fresh diets to broodstock growth, reproductive performance and larvae of Lysmata amboinensis. J. Environ. Biol., 41, 1249-1256 (2020). 


\section{Introduction}

The marine ornamental trade started in 1930s, and currently the rising popularity has made it a global multi-million Euro industry (Rhyne et al., 2012; Leal et al., 2016b). Presently, most of the ornamental species captured from coral reefs area have been documented to be critically endangered are due to direct or indirect threats associated with human activities (Leal et al., 2012; Thornhill, 2012), leading to biodiversity reduction and ecological imbalances (Lin et al., 2002; Bunting, 2003). Captive breeding of ornamental species lessen strain on coral reefs besides meeting the increasing market demands (Leal et al., 2016a). In recent years, ornamental shrimp has become one of the top traded invertebrates along, with some species of genera Lysmata and Stenopus, which represents the highest commodity of shrimps traded in the marine aquarium industry (Calado et al., 2017). The increasing demand for certain species, which consists of high value white-striped cleaner shrimp, L. amboinensis, have threatened the sustainability of this species. L. amboinensis known as protandric simultaneous hermaphrodite (PSH) (Bauer, 2000), where it is born as a male and later, it will change into simultaneous, true hermaphroditism, which omits self-fertilization (Fiedler, 1998). Therefore, the energetic requirements of oogenesis and spermatogenesis must be satisfied via brood stock diets (Calado et al., 2009). With the exception of certain species, particularly in the genus Macrobrachium, the knowledge and information of nutritional requirements for Caridean shrimp broodstock (Harrison, 1990) including L. amboinensis are still scarce. In view of the above, this research was conducted with the aim to assess the effects of widely available diets (fresh frozen mussel, squid, and polychaetes, as well as mixture of mentioned feeds) to $L$. amboinensis broodstock that can minimize the production cost, and the effects were evaluated based on broodstock conditions, reproductive performances, larval quality and biochemical compositions via proximate analyses and fatty acid profile.

\section{Materials and Methods}

Broodstock maintenance and collection of larvae : This work used following acclimation, the 12 pairs of $L$. amboinensis brood stock shrimp brood stocks with average total length ( $45.95 \pm 0.59$ $\mathrm{mm}),(p<0.05)$ were paired and transferred to the experimental tanks $(0.40 \mathrm{~m} \times 0.21 \mathrm{~m} \times 0.29 \mathrm{~m})$ using under gravel system with constant aeration. Water temperature $\left(25^{\circ} \mathrm{C} \pm 1{ }^{\circ} \mathrm{C}\right)$, salinity $(30$ ppt) and pH (7.98 \pm 0.1$)$ were stable throughout the experimental period. The aquaria were provided with around 2-cm thick layer small pebbles as a substrate of and dead corals for shelter with proper monitoring of ammonia and nitrites .Brood stocks were fed with chopped squid, mussel, and polychaetes ad libitum once dailyor on alternate days. Shrimp with eggs in complete embryo stage were separated and individually held in hatching tank with proper aeration. The larvae were gathered using light trap and gently harvested using a sieve $(300 \mu \mathrm{m})$ and measured.
Experimental procedure : The four dietary treatments with three replicates entailing two shrimps.

Asian green mussel, Perna viridis, cut up in pieces sized between 2-3 mm; Squid, Loligo sp., cut up in pieces sized between 2-3 mm; Polychaetes, Marphysa moribidii, cut up in pieces sized between 2-3 $\mathrm{mm}$ and Mussel, squid, as well as polychaetes ( $m i x$ diet) that are fed in succession of days.

The amount of food was Hettiarachchi and Edirisinghe (2016), equivalent to $5 \%$ of total body weight, fed twice daily (morning and evening) and taking account on preliminary observations of consumption and daily feeding response. Before collecting the data, the broodstock were fed with experimental diets for two moult cycles to permit acclimatization with the diet treatments, as well as to reduce the consequences of former maintenance diet.

Parameters recorded : Parameters measured for egg retention under abdomen (\%), viable fecundity and fecundity were based on the study of Tziouveli et al. (2011). Feeding data collection was done for every replicate in a successive spawn. The experimental parameters recorded were: Broodstock survival (\%) expressed as percentage of shrimp survived at the end of study; Broodstock growth (\%) expressed as percentage of increase in the initial size for overall length ( $T L)$, carapace length (CL), as well as carapace width $(\mathrm{CW})$ of the broodstock at the end of the study and Egg retention under abdomen (\%) is denoted as the percentage of eggs available at the carrying area throughout the incubation period. No spawn is indicated by zero percent, while $100 \%$ refers to the overall egg cover. The data was recorded every two days and was calculated by the formula:

\footnotetext{
The egg mass volume occupied in the abdominal egg carrying area (length $\times$ width $\times$ depth) $\left(\mathrm{mm}^{3}\right)$

$\overline{\text { Abdominal length } \times \text { abdominal width } \times \text { abdominal depth }\left(\mathrm{mm}^{3}\right)}$ $x 100$
}

Viable fecundity refers to the amount of larvae hatched at a successful spawning event; Egg fecundity was expressed as a number of fertile egg at a successful spawning event. Individual eggs were counted with the help of a dissection microscope (Olympus SZ51 - LGB, Olympus Corporation, Tokyo, Japan) and Larval morphometric data (TL, CL and CW) were measured with a digital microscope Dino-Lite equipped with DinoCapture 2.0 software based on triplicates result for each treatments $(n=90)$.

Proximate analyses: Gross proximate composition of food items used were evaluated following the methodology of Association of Official Analytical Chemists (AOAC, 1997).

Fatty acid profiles : The overall total fatty acids were drawn out from feeds, tissues and plasma via the technique of Folch et al. (1957) with modification by Rajion et al. (1985). FAME were 
analysed with GC column (Agilent 7890N) and a $30 \mathrm{~m} \times 0.25 \mathrm{~mm}$, and $0.25-\mu \mathrm{m}$ coating thickness Supelco SP-2330 Capillary Column (Supelco, Inc., Bellenfonte, PA, USA).

Statistical analyses : One-way ANOVA was applied to detect possible significant differences of all reproductive parameters involved in the study using the software IBM SPSS (predictive analytics software). The percentage of egg cover under abdomen across the incubation time was compared based on the final percentage value during the incubation period. Duncan's Multiple Range Test was applied of ANOVA indicated a huge dissimilarity $(p<0.05)$.

\section{Results and Discussion}

The survival rate of $L$. amboinensis brood stocks were unchanged by the experimental diets because there was an absence of mortalities recorded throughout the study period. The findings demonstrated the suitability of all diets for the general maintenance of broodstocks. Similarly, Tziouveli et al. (2011) also reported that the broodstock of this species were able to survive when fed with squid (Loligo opalescens), mussel (Perna canaliculus), artemia and pellet (commercial Kuruma prawn diet,
Ebi Star, Higashimaru, Japan). This showed that this species was easy to maintain due to its hardiness and not fussy in choosing its diet. Apart from its fascinating external morphology and interesting behavior, this may also be a factor that causes marine shrimp hobbyists to rear this shrimp in their ornamental aquarium.

Fig. 1 shows no significant difference in all parameters for broodstocks growth (total length, carapace length and carapace width) in the different diet treatments over the experimental period $(p>0.05)$. The insignificant growth rate recorded for brood stock could be related to almost similar protein content percentage of all diets in the experiment which ranged from $63.93 \%$ to $75.10 \%$. Moreover, the reproductive event in brood stocks takes up great amount of energy, thus, there was an expectation on the absence of growth throughout this experiment. The simultaneous hermaphrodites did not exhibit growth as a significant portion of their energy directed to oocyte production, thus, producing slower growth rates. Bolognini et al. (2017) mentioned that an extraordinary amount of energy required in the reproductive event as an investment to ensure offsprings' survival.

Fig. 2 shows mussel, polychaetes and mix diets displayed high percent of egg cover at the end of incubation
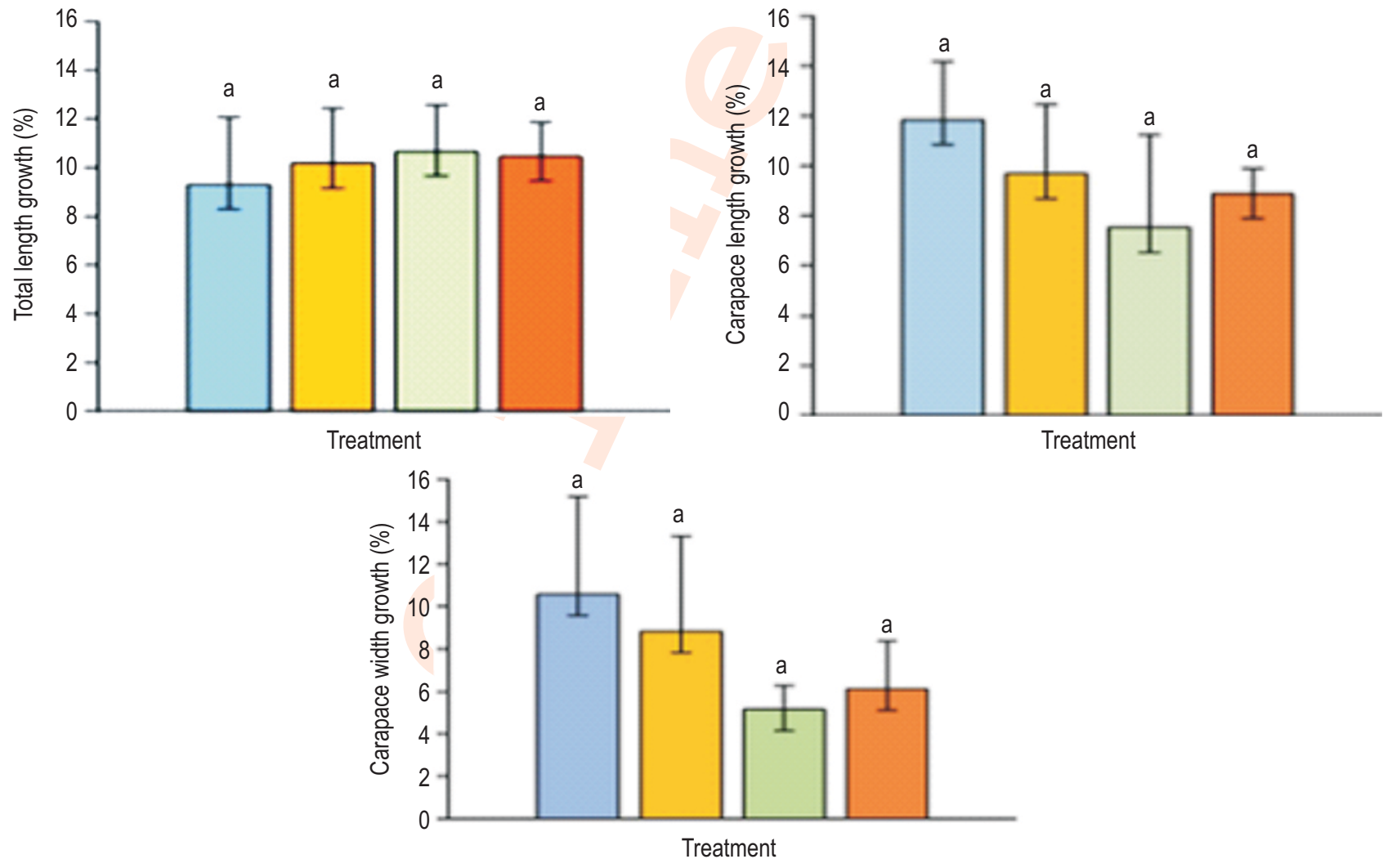

$$
\square \text { Mussel } \quad \square \text { Squid } \quad \square \text { Polycheates }
$$

Fig. 1 : Growth rate of Lysmata amboinensis broodstock (percentage increment in total length, carapace length and carapace width) over the span of study under different diets (means $\pm S . E, n=3$ replicates per treatment). 
period $(90.33 \%, 83.67 \%$ and $85.33 \%)$ without a great difference $(p>0.05)$. Besides, these three diets also demonstrated similar egg loss over the course of 17 days with reduction of approximately $10 \%-16 \%$. Squid diet had the lowest initial egg cover $(85.0 \%)$ and the highest egg loss during incubation $(58.67 \%)(p<0.05)$. Squid contained the highest level of protein $(75.10 \%)$ and polychaetes had the highest amount of lipid (12.05\%) (Table 1). Lipid component offers suitable energy sources for broodstock maturation and continuous spawning event as it related to the production of reproductive tissue (Naessens et al., 1997).

Feeds showed significant effect on egg fecundity $(p<$ 0.05) (Fig. 3). The broodstock fed with mussel diet produced the highest fecundity (1985), followed by mix diet (1905), polycheates (1667) and squid (959). As the percent of egg cover under abdomen reduced throughout the incubation period, it totally affected the viable fecundity at the end of the study. Proximate analyses showed that squid had the lowest lipid content resulting in poor spawning performance as the broodstock fed with squid showed reduced egg fecundity and poorer egg retention. Although polychaetes contained the highest amount of lipid, too high of lipid content may negatively affect the ingestion rate because the shrimp broodstoock tend to be satisfied when reached their energy requirements (Aranyakananda and Lawrence, 1994), hence causing nutrient deficiencies (D'Abramo, 1997). The mussel diet produced the highest number of larvae (568), followed by polychaetes and mix diets (391 and 386, respectively) (Fig. 4). Shrimp fed with squid showed significantly low $(p<0.05)$ reproductive output $(97)$. Examining the experimental diets in the aspect of fatty acid profile and broodstock body can deliver some possible clarifications.

The fatty acid content in the experimental diets, especially 14:0, 16:1, OA, DHA, MUFA and PUFA n-6 showed critical difference between the treatments $(p<0.05)$ (Table 2). All diets showed high contents of total PUFA and SFA without critical difference among the experimental diets $(p>0.05)$. The diet mussel showed a paramount level in 14:0 (Myristic) and 16:1 (Palmitoleic), while polychaetes displayed the highest contents of 18:1n-9, total MUFA and total PUFA $n-6$. The squid diet showed high level of DHAand overall PUFAn-3, but very low in total MUFA compared to other diets, $(p<0.05)$. Tziouveli (2011) reported that shrimp fed with mussel-squid displayed the lowest production of L. amboinensis larvae (22). However, in this study, feeding broodstock with mussel alone produced the highest viable fecundity (568). DHA level seemed to play critical role in egg retention, fecundity and early larvae production. This hypothesis is also supported by the result of previous study done by Wen et al. (2002) that DHA has a function in early embryogenesis that affects the hatchability of eggs. High DHAlevel has been reported in broodstock diet improved embryogenesis and early larval development (Xu et al. 1994; Cahu et al. 1995). Cahu et al. (1995)

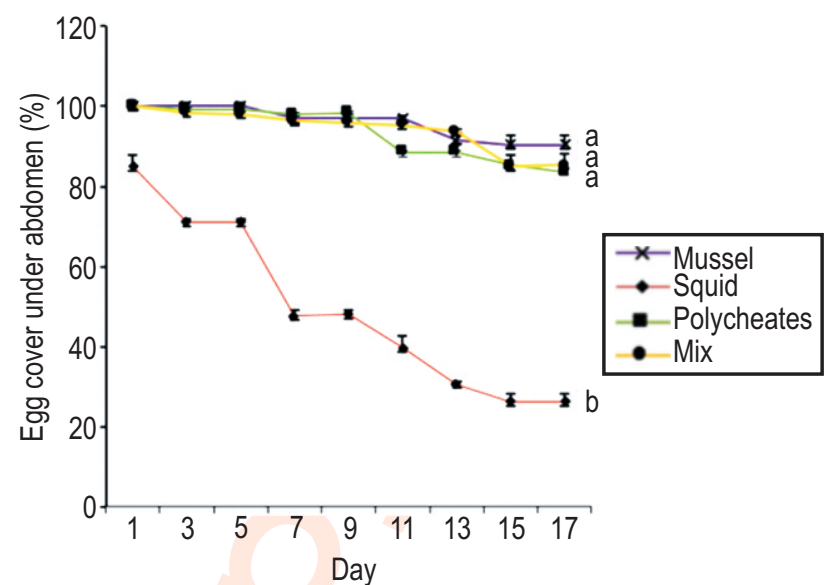

Fig. 2 : Egg cover expressed as a percentage of total egg incubate area during 17 days incubation period for different diets (means \pm S.E, $n=3$ replicates per treatment). Different letters show significant difference in egg cover percentage, $(p<0.05)$.

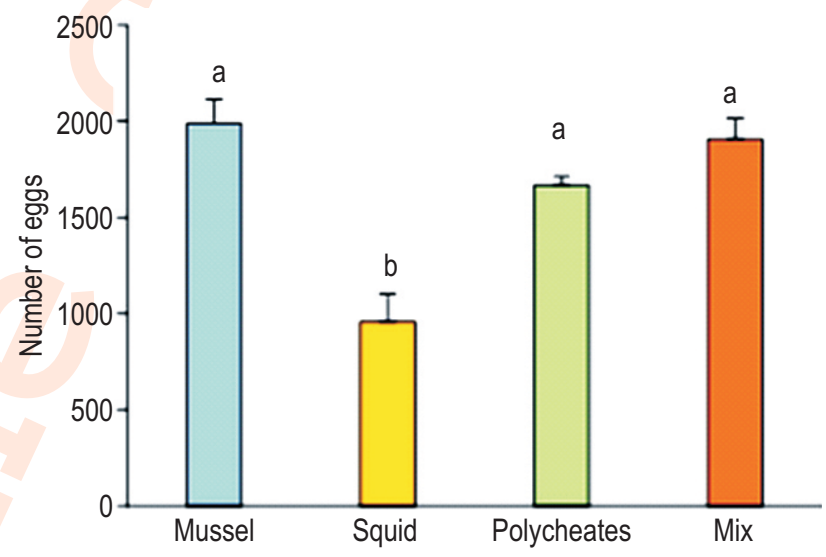

Fig. 3 : Fecundity for each diets treatment. Different letters show significant difference between diets treatments for fecundity $(p<0.05)$ (means \pm S.E, $n=3$ replicates per treatment).

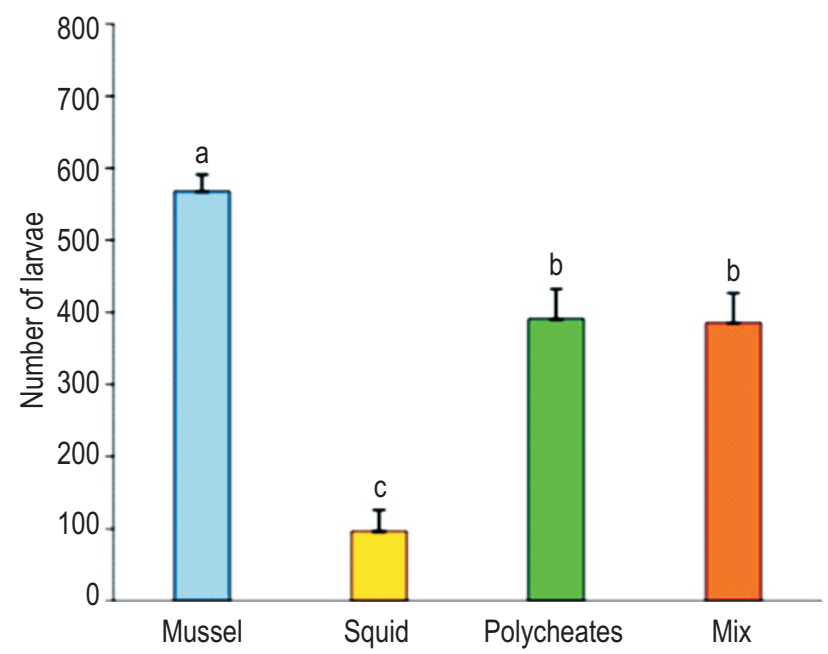

Fig. 4 : Viable fecundity for each diets treatment. Different letters show significant difference between diets treatments for viable fecundity $(p<$ 0.05 ) (means $\pm S E, n=3$ replicates per treatment). 
Table 1 : Proximate composition of experimental diets used to feed $L$. amboinensis broodstocks (expressed as $\%$ dry matter basis)

\begin{tabular}{llll}
\hline & Mussel & Squid & Polychaetes \\
\hline Crude protein & $69.74 \pm 0.49^{\mathrm{ab}}$ & $75.10 \pm 0.26^{\mathrm{a}}$ & $63.93 \pm 0.33^{\mathrm{b}}$ \\
Crude lipid & $7.62 \pm 0.23^{\mathrm{b}}$ & $1.79 \pm 0.01^{\mathrm{c}}$ & $12.05 \pm 0.64^{\mathrm{a}}$ \\
Crude carbohydrates & $12.71 \pm 0.16^{\mathrm{b}}$ & $18.51 \pm 0.32^{\mathrm{a}}$ & $13.42 \pm 0.07^{\mathrm{b}}$ \\
Moisture & $72.09 \pm 0.27^{\mathrm{b}}$ & $82.25 \pm 0.15^{\mathrm{a}}$ & $80.25 \pm 0.83^{\mathrm{a}}$ \\
Ash & $9.93 \pm 0.20^{\mathrm{a}}$ & $4.60 \pm 0.47^{\mathrm{b}}$ & $10.60 \pm 0.66^{\mathrm{a}}$ \\
\hline
\end{tabular}

Values are means of triplicate samples $( \pm$ S.E). Different letters showed significant difference between diets treatments $(p<0.05)$

Table 2 : Fatty acid content ( $\%$ of total fatty acids) of experimental diets used to feed $L$. amboinensis broodstock

\begin{tabular}{llll}
\hline Fatty acid profiles & Mussel & Squid & Polychaetes \\
\hline $14: 0$ & $9.13 \pm 0.38^{\mathrm{a}}$ & $5.69 \pm 0.43^{\mathrm{b}}$ & $4.61 \pm 1.55^{\mathrm{b}}$ \\
$16: 0$ & $19.29 \pm 0.49^{\mathrm{a}}$ & $24.55 \pm 3.74^{\mathrm{a}}$ & $23.68 \pm 3.76^{\mathrm{a}}$ \\
$16: 1$ & $11.52 \pm 0.43^{\mathrm{a}}$ & $5.14 \pm 1.25^{\mathrm{b}}$ & $4.74 \pm 0.68^{\mathrm{b}}$ \\
$18: 0(\mathrm{SA})$ & $10.98 \pm 1.23^{\mathrm{a}}$ & $12.91 \pm 2.32^{\mathrm{a}}$ & $14.24 \pm 0.54^{\mathrm{a}}$ \\
$18: 1 \mathrm{n}-9(\mathrm{OA})$ & $4.82 \pm 0.87^{\mathrm{b}}$ & $6.11 \pm 0.94^{\mathrm{b}}$ & $11.95 \pm 2.21^{\mathrm{a}}$ \\
$18: 2 \mathrm{n}-6($ LOA $)$ & $2.35 \pm 0.39^{\mathrm{a}}$ & $6.13 \pm 1.25^{\mathrm{a}}$ & $9.85 \pm 3.65^{\mathrm{a}}$ \\
$18: 3 \mathrm{n}-3($ ALA) & $4.63 \pm 0.58^{\mathrm{a}}$ & $4.40 \pm 0.70^{\mathrm{a}}$ & $5.37 \pm 0.48^{\mathrm{a}}$ \\
$20: 4 \mathrm{n}-6(\mathrm{AA})$ & $8.37 \pm 0.73^{\mathrm{a}}$ & $6.09 \pm 0.67^{\mathrm{a}}$ & $10.58 \pm 1.98^{\mathrm{a}}$ \\
$20: 5 \mathrm{n}-3$ (EPA) & $9.77 \pm 0.31^{\mathrm{a}}$ & $7.48 \pm 0.45^{\mathrm{b}}$ & $4.37 \pm 0.78^{\mathrm{b}}$ \\
$22: 5 \mathrm{n}-3$ (DPA) & $9.17 \pm 2.15^{\mathrm{a}}$ & $9.72 \pm 1.35^{\mathrm{a}}$ & $8.19 \pm 0.61^{\mathrm{a}}$ \\
$22: 6 \mathrm{n}-3$ (DHA) & $9.98 \pm 1.55^{\mathrm{b}}$ & $14.16 \pm 1.68^{\mathrm{a}}$ & $5.76 \pm 1.92^{\mathrm{b}}$ \\
$\Sigma$ SFA & $39.40 \pm 1.48^{\mathrm{a}}$ & $41.59 \pm 5.06^{\mathrm{a}}$ & $42.53 \pm 2.61^{\mathrm{a}}$ \\
$\Sigma$ MUFA & $16.34 \pm 1.04^{\mathrm{a}}$ & $10.99 \pm 0.76^{\mathrm{b}}$ & $16.69 \pm 1.58^{\mathrm{a}}$ \\
$\Sigma$ PUFA & $44.27 \pm 2.50^{\mathrm{a}}$ & $47.97 \pm 3.79^{\mathrm{a}}$ & $44.12 \pm 0.71^{\mathrm{a}}$ \\
$\Sigma$ PUFAn-3 & $33.55 \pm 2.58^{\mathrm{ab}}$ & $35.50 \pm 3.90^{\mathrm{a}}$ & $23.68 \pm 2.72^{\mathrm{b}}$ \\
$\Sigma$ PUFAn-6 & $10.72 \pm 1.09^{\mathrm{b}}$ & $11.92 \pm 0.84^{\mathrm{b}}$ & $18.09 \pm 2.16^{\mathrm{a}}$ \\
\hline
\end{tabular}

Values are means of triplicate samples \pm S.E. Different superscript letters in the same column represent significant differences $(p<0.05)$; $\Sigma$ Saturated fatty acid (SFA): 14:0, 16:0, 18:0 $\Sigma$ Monounsaturated fatty acid (MUFA): 16:1, 18:1n-9 $\Sigma$ Polyunsaturated fatty acid (PUFA): 18:2n-6, 18:3n$3,20: 4 n-6,20: 5 n-3,22: 5 n-3,22: 6 n-3$

showed that at high DHA level in the $\operatorname{diet}(17.5 \%$ to $19.8 \%$ of total fatty acid), eggs of Penaeus indicus are able to incorporate this level of DHAwhich is sufficient for adequate hatching.

However, the results of this study contradict to the well documented function of DHA in the reproduction response, particularly in embryogenesis and early larval development of penaeid shrimp. Higher DHA content in squid diet $(14.16 \%$ of total fatty acid) affected the egg retention and gave the lowest egg fecundity. Previously, in penaeids shrimp, Bray et al. (1990) also reported that extremely high content of $\mathrm{DHA}$ may result in low hatchability because it becomes negatively inhibitory, which affects the level of other important fatty acids. Tziouveli et al. (2011) suggested that the high DHA level in squid may partly clarify the effect of lesser egg cover prior to hatch conceding egg production in L. amboinensis. Tziouveli et al. (2012) later showed that DHA content of $11 \%$ administered to broodstock of $L$. amboinensis contributed the optimal outcome for embryo hatchability, as well as succeeding larval production. Figueiredo et al. (2008) reported that low consumption of DHA during embryogenesis based on fatty acid profiles of $A$. cinereum eggs showed that there may not be a requirement for DHA-rich diet for this specie. This also proved the amount of DHA in the diet to fulfil the broodstock requirement for better reproduction performance in terms of embryogenesis, egg retention, fecundity which finally lead to larval production, were species dependent.

Diet treatments have significant effect on larval morphometric (total length, carapace length and carapace width) (Table 3). In this study, larvae produced from broodstock fed with squid displayed higher value of body total length and produced bigger head in terms of their carapace width measurement. The findings suggest that significant larval morphometric may be related to high DHA contents in the squid diet. Narciso and Morais (2001) reported an extremely high amount of DHAin the brain and retina that play a specific role in neural and visual membrane systems (Sargent, 1995). Martin et al. (1994) demonstrated that the presence of DHA in high concentrations in phospholipids from the brain, retina and testes is unusual, and it plays an essential role in the development of central nervous system. Mourente and 
Table 3 : Larval morphometric measurements of $L$. amboinensis under different diet treatments

\begin{tabular}{llll}
\hline Treatment & Total length & Carapace length & Carapace width \\
\hline Mussel & $2.62 \pm 0.02^{\mathrm{b}}$ & $0.91 \pm 0.01^{\mathrm{a}}$ & $0.48 \pm 0.00^{\mathrm{b}}$ \\
Squid & $2.69 \pm 0.01^{\mathrm{a}}$ & $0.69 \pm 0.00^{\mathrm{C}}$ & $0.52 \pm 0.00^{\mathrm{a}}$ \\
Polychaetes & $2.43 \pm 0.01^{\mathrm{b}}$ & $0.90 \pm 0.01^{\mathrm{a}}$ & $0.47 \pm 0.00^{\mathrm{b}}$ \\
Mix & $2.41 \pm 0.01^{\mathrm{c}}$ & $0.87 \pm 0.00^{\mathrm{b}}$ & $0.48 \pm 0.00^{\mathrm{b}}$ \\
\hline
\end{tabular}

Different letters showed significant difference between diets treatments $(p<0.05)$ (means $\pm S . E, n=90$ replicates per treatment)

Table 4 : Fatty acid composition (\% of total fatty acids) of $L$. amboinensis broostock fed with different diets

\begin{tabular}{|c|c|c|c|c|}
\hline Fatty acid profiles & Mussel & Squid & Polychaetes & Mix \\
\hline $14: 0$ & $5.01 \pm 0.27^{\mathrm{a}}$ & $3.00 \pm 0.36^{\mathrm{a}}$ & $5.67 \pm 2.14^{\mathrm{a}}$ & $4.47 \pm 1.11^{\mathrm{a}}$ \\
\hline $16: 0$ & $18.09 \pm 0.72^{\mathrm{a}}$ & $22.37 \pm 3.72^{\mathrm{a}}$ & $20.33 \pm 0.01^{\mathrm{a}}$ & $19.40 \pm 0.46^{\mathrm{a}}$ \\
\hline $16: 1$ & $7.47 \pm 0.42^{\mathrm{ab}}$ & $5.63 \pm 1.57^{b}$ & $11.55 \pm 1.67^{\mathrm{a}}$ & $9.86 \pm 1.41^{\mathrm{ab}}$ \\
\hline $18: 0(\mathrm{SA})$ & $16.46 \pm 0.33^{\mathrm{a}}$ & $13.06 \pm 2.2^{\mathrm{ab}}$ & $12.50 \pm 0.16^{\mathrm{ab}}$ & $11.97 \pm 0.95^{b}$ \\
\hline $18: 1 n-9(O A)$ & $16.78 \pm 0.65^{\mathrm{a}}$ & $17.47 \pm 11.16^{\mathrm{a}}$ & $19.89 \pm 1.13^{\mathrm{a}}$ & $17.78 \pm 1.59^{\mathrm{a}}$ \\
\hline $18: 2 n-6(L A)$ & $2.20 \pm 0.79^{b}$ & $4.01 \pm 0.27^{\mathrm{a}}$ & $3.24 \pm 0.14^{\mathrm{ab}}$ & $2.37 \pm 0.35^{b}$ \\
\hline $18: 3 n-3($ ALA) & $2.72 \pm 0.13^{\mathrm{a}}$ & $2.37 \pm 0.03^{\mathrm{ab}}$ & $2.17 \pm 0.73^{\mathrm{ab}}$ & $1.36 \pm 0.02^{b}$ \\
\hline $20: 4 n-6(A A)$ & $8.62 \pm 0.67^{\mathrm{ab}}$ & $7.48 \pm 0.53^{b}$ & $11.12 \pm 0.14^{\mathrm{ab}}$ & $13.97 \pm 3.06^{\mathrm{a}}$ \\
\hline $20: 5 n-3$ (EPA) & $11.99 \pm 0.81^{\mathrm{a}}$ & $6.08 \pm 0.38^{b}$ & $3.44 \pm 0.62^{\circ}$ & $6.35 \pm 0.40^{\mathrm{b}}$ \\
\hline $22: 5 n-3(\mathrm{DPA})$ & $4.41 \pm 0.92^{\mathrm{a}}$ & $9.93 \pm 3.22^{\mathrm{a}}$ & $7.98 \pm 2.17^{\mathrm{a}}$ & $5.87 \pm 1.60^{\mathrm{a}}$ \\
\hline 22:6n-3 (DHA) & $6.23 \pm 0.00^{\mathrm{a}}$ & $8.58 \pm 1.64^{a}$ & $2.11 \pm 0.78^{b}$ & $7.61 \pm 0.66^{a}$ \\
\hline$\Sigma$ SFA & $39.57 \pm 0.65^{a}$ & $38.43 \pm 5.58^{\mathrm{a}}$ & $38.50 \pm 2.31^{a}$ & $34.85 \pm 1.23^{\mathrm{a}}$ \\
\hline$\Sigma$ MUFA & $24.25 \pm 1.07^{b}$ & $23.09 \pm 0.10^{c}$ & $31.44 \pm 0.53^{\mathrm{a}}$ & $27.64 \pm 0.18^{\mathrm{ab}}$ \\
\hline$\Sigma$ PUFA & $36.17 \pm 1.72^{\mathrm{a}}$ & $38.46 \pm 5.48^{\mathrm{a}}$ & $30.05 \pm 2.83^{b}$ & $37.52 \pm 1.40^{\mathrm{a}}$ \\
\hline$\Sigma$ PUFAn-3 & $25.35 \pm 1.60^{\mathrm{ab}}$ & $26.97 \pm 5.22^{\mathrm{a}}$ & $15.70 \pm 2.84^{\mathrm{b}}$ & $21.18 \pm 1.32^{\mathrm{ab}}$ \\
\hline$\Sigma$ PUFAn-6 & $10.83 \pm 0.12^{d}$ & $11.50 \pm 0.26^{c}$ & $14.36 \pm 0.00^{\mathrm{b}}$ & $19.05 \pm 0.00^{\mathrm{a}}$ \\
\hline
\end{tabular}

Values are means of triplicate samples \pm S.E. Different superscript letters in the same column represent significant differences $(p<0.05)$. $\Sigma$ Saturated fatty acid (SFA): 14:0, 16:0, 18:0 $\Sigma$ Monounsaturated fatty acid (MUFA): 16:1, 18:1n-9 $\Sigma$ Polyunsaturated fatty acid (PUFA): 18:2n-6, 18:3n-3, 20:4n-6, 20:5n-3, 22:5n-3, 22:6n-3

Tocher (1992) claimed how DHA influences the brain weight and composition of fatty acid of turbot, Scophthalmus maximus $L$. as DHA was found specifically accumulated in brain lipid. Moreover, Suprayudi et al. (2004) reported that the larvae of mud crab require high amount of DHA and EPA at appropriate levels for maintaining high survival and produce good quality larvae in terms of carapace size. In another research, Takeuchi et al. (1999) described that DHA plays an important role in increasing carapace width of swimming crab larvae. Therefore, we summarized that higher DHAin squid might have relationship that give effect to the larval morphometric measurement, in terms of producing the longest total length and widest carapace size of $L$. amboinensislarvae.

The results obtained in the present study suggested that high concentration of monounsaturated fatty acid (MUFA) with focusing in significant higher content of 16:1 (Palmitoleic) in mussel, may assist metabolic functioning and support energy requirements during the embryonic development which finally could be associated for better egg retention and high egg production compared to other diets. As mentioned by Balina et al.
(2018), reproductive event in broodstocks uses great amount of energy. It is broadly acknowledged that MUFA is utilized to provide energetic function (Cavalli et al., 2001; Rosa et al., 2003). This hypothesis was supported by shrimp body fatty acid evaluation as it showed that shrimp fed with squid have the lowest amount of MUFA (Table 4), which reflected insufficient energy in the body to serve and maintain the reproductive event and finally produce low larvae output.

Simoes et al. (1998) and Lin and Zhang (2001) elucidated that different broodstock diets of $L$. amboinensis and $L$. wurdemanni seemed to have no effect on their reproductive performance. In contrast to this study, the diet treatments led to marked variances in the reproductive output of $L$. amboinensis. Broodstock diet is well known to give major impact in shrimp's reproduction (Lin and Shi, 2002). According to Lin et al. (2002), diet nutritional equitableness is species dependent. It affects various elements of reproduction, thus influencing the nutritional profile and broodstock nutritional necessities. The diet appears to have an impact on the egg cover during incubation, egg fecundity, viable fecundity and output in terms of larval morphometric of $L$. amboinensis. 
However, it should be noted that reproductive performance may be related not only on lipid and fatty acid contents, but also sufficient amount of vitamins, minerals and carotenoids (Perez-Velazquez et al., 2003; Williams, 2007). Mussel, Perna viridis also has content of high vitamin A, minerals like calcium, potassium, sodium, iodine and amino acid, methionine (Saritha et al., 2015) and is used regularly as broodstock diet for penaeid shrimp (Hertrampf and PiedadPascual, 2000; FAO, 2007).

Broodstock diet influence the egg cover during incubation, egg fecundity, viable fecundity and the output in terms of $L$. amboinensis larval morphometry. Through fatty acid profile analyses, it was possible to evaluate effect of different diet on reproductive performance of $L$. amboinensis. The results showed that the content of MUFA in the diet correlates well with the egg production of this cleaner shrimp, whereas the level of 22: $6 \mathrm{n}-3$ $(\mathrm{DHA})$ in the diet exhibited close relation with the egg retention throughout the incubation period. These relationships suggest that MUFA may play some potential role in the embryonic development process related to fecundity whereas DHA may play some other role in early embryogenesis related to egg hatchability and larval morphometric of $L$. amboinensis. This information provides a better understanding on this species nutrition demand which is important to increase the chances of mass production to meet the industry demand in future.

\section{Acknowledgments}

This study was funded by an internal grant from Universiti Putra Malaysia (UPM); project no GP-IPB/2014/9440403. We thank the staff at the International Institute of Aquaculture and Aquatic Sciences (I-AQUAS), Universiti Putra Malaysia for their assistance during the conduct of this experiment.

\section{References}

Aranyakananda, P. and A.L. Lawrence: Effects of ingestion rate on dietary protein and energy requirements of Penaeus vannamei and the optimal protein to energy ratio. Memorias 2 Simposio en Nutricion'Acuıcola. Monterrey, Mexico, pp. 1-19 (1994).

Association of Official Analytical Chemists (AOAC): Official Methods of Analysis of AOAC International. Washington, USA: AOAC International (1997).

Balina, S., B. Temperoni, L. Susana, L. Greco and C. Tropea: Losing reproduction: Effect of high temperature on female biochemical composition and egg quality in a freshwater crustacean with direct development, the red cherry shrimp, Neocaridina davidi (decapoda, atyidae). Biol. Bull., 234, 000-000 (2018).

Bauer, R.T.: Simultaneous hermaphroditism in caridean shrimps: A unique and puzzling sexual system in the decapoda. $J$. Crustacean Biol., 20, 116-128 (2000).

Bolognini, L., F. Donato, A. Lucchetti, I. Olivotto, C. Truzzi, B. Randazzo, M. Antonucci, S. Illuminati and F. Grati: A multidisciplinary approach to study the reproductive biology of wild prawns. Sci. Rep., 7, 1-12(2017).
Bray, W.A., A.L. Lawrence and L.J. Lester: Reproduction of eyestalk ablated Penaeus stylirostris fed various levels of total dietary lipid. J. World Aquacult. Soc., 21, 41-52 (1990).

Bunting, B.W., P. Holthus and S. Spalding: The marine aquarium industry and reef conservation. In: Marine ornamental species: collection, culture \& conservation (Eds.: J.C. Cato and C.L. Brown). lowa State Press. pp. 109-124 (2003).

Cahu, C.L., G. Cuzon and P. Quazuguel: Effect of highly unsaturated fatty acids, a-tocopherol and ascorbic acid in broodstock diet on egg composition and development of Penaeus indicus. Comp. Biochem. Phys., 112, 417-424 (1995).

Calado, R., I. Olivotto, M.P. Oliver and J. Holt: Marine Ornamental Species Aquaculture. U. K: Wiley-Blackwell (2017).

Calado, R., A. Vitorino, A. Reis, T. Lopes Da Silva and M.T. Dinis: Effect of different diets on larval production, quality and fatty acid profile of the marine ornamental shrimp Lysmata amboinensis (de Man, 1888), using wild larvae as a standard. Aquacult. Nutr., 15, 484491 (2009).

Cavalli, R.O., M. Tamtin, P. Lavens and P. Sorgeloos: Variation in lipid classes and fatty acid content in tissues of wild Macrobrachium rosenbergii (de Man) females during maturation. Aquacult., 193, 311-324 (2001).

D'Abramo, L.R.: Triacylglycerol and fatty acids. In: Crustacean Nutrition (Ed.: E. Halver), World Aquaculture Society. Vol. 6, pp. 71-84 (1997).

Fiedler, G.C.: Functional, simultaneous hermaphroditism in femalephase Lysmata amboinensis (Decapoda: Caridea: Hippolytidae). Pac. Sci., 52, 161-169 (1998).

Figueiredo, J., G., Penha-Lopes, J. Anto, L. Narciso and J. Lin: Fecundity, brood loss and egg development through embryogenesis of Armases cinereum (decapoda: grapsidae). Mar. Biol., 154, 287-294 (2008).

Folch, A.J., M. Less and G.H.S. Stanley: A simple method for isolation and purification of total lipids from animal tissues. J. Biol. Chem., 226, 497-509 (1957).

Food and Agriculture Organization (FAO): Aquaculture management and conservation service. Improving Penaeus monodon hatchery practices. Manual based on experience in India. Fisheries Technical Paper. Retrieved June 7, 2018, from http://www.fao.org/ documents/card/en/c/0e6b8d11-81ed-5afb-b37406605dbe01d1/. (2007).

Harrison, K.E.: The role of nutrition in maturation, reproduction and embryonic development of decapod crustaceans: A review. J. Shellfish Res., 9, 1-28 (1990).

Hertrampf, J. W. and F. Piedad-Pascual: Mollusc Products. In: Handbook on ingredients for aquaculture feeds. (Eds.: J.W. Hertrampf and F. Piedad-Pascual), Springer, pp. 314-321 (2000).

Hettiarachchi, H.A.S.U. and U. Edirisinghe: Captive breeding of fire shrimp (Lysmata debelius) under Sri Lankan conditions. Trop. Agric. Res., 28, 88-99 (2016).

Leal, M.C., J. Puga, J. Serodio, N.C.M. Gomes and R. Calado: Trends in the discovery of new marine natural products from invertebrates over the last two decades - where and what are we bioprospecting?. PLoS ONE, 7, 1-15 (2012).

Leal, M.C., R.J.M. Rocha, R. Rosa and R. Calado: Aquaculture of marine non-food organisms: what, why and how? Rev. Aquacult., 1-24 (2016a).

Leal, M.C., M.C.M. Vaz, J. Puga, R.J.M. Rocha, C. Brown, R. Rosa and R. Calado: Marine ornamental fish imports in the European Union: 
An economic perspective. Fish Fish., 17, 459-468 (2016b).

Lin, J. and D. Zhang: Effect of broodstock diet on reproductive performance of the peppermint shrimp, Lysmata wurdemanni. J. Shellfish Res., 20, 361-363 (2001).

Lin, J. and P. Shi: Effect of broodstock diet on reproductive performance of the golden banded coral shrimp Stenopus scutellatus. J. World Aquacult. Soc., 33, 383-386 (2002).

Lin, J., D. Zhang and A. Rhyne: Broodstock and larval nutrition of marine ornamental shrimp. In: Avances em Nutrición Acuícola VI. Memorias del VI. (Eds.: L.E. Cruz-Suaréz, D. Ricque-Marie, M. Tapia-Salazar, M.G. Graxiola-Cortés and N. Simoes), Cancun, Mexico: Simposium Internacional de Nutrición Acuícola, pp. 277280 (2002).

Martin, R.X., E.B.R. Turco and N.G. Bazan: Developmental maturation of hepatic n-3 polyunsaturated fatty acid metabolism: Supply of docosahexaenoic acid to retina and brain. J. Nutr. Biochem., 5, 151-160 (1994).

Mourente, G. and D.R. Tocher: Effects of weaning onto a pelleted diet on docosahexaenoic acid (22:6n-3) levels in brain of developing turbot (Scophthalmus maximus). Aquac., 105, 363-377 (1992).

Naessens, E., P. Lavens, L. Gomez, C. Browdy, K. McGovern-Hopkins, A. Spencer, D. Kawahigashi and P. Sorgeloos: Maturation performance of Penaeus vannamei co-fed Artemia biomass preparations. Aquac., 155, 87-101 (1997).

Narciso, L. and S. Morais: Fatty acid profile of Palaemon serratus (palaemonidae) eggs and larvae during embryonic and larval development using different live diets. J. Crustacean Biol., 21, 566574 (2001).

Perez-Velazquez, M., M.L. Gonzalez-Felix, A.L. Lawrence, W.A. Bray and D.M. Gatlin: Dietary effects on sperm quality of Litopenaeus vannameibroodstock. J. World Aquacult Soc., 34, 92-98 (2003).

Rajion, M.A., J.G. McLean and R.N. Cahill: Essential fatty acids in the fetal and newborn lamb. Aust. J. Biol. Sci., 38, 33-40 (1985).

Rhyne, A.L., M.F. Tlusty and L. Kaufman: Long-term trends of coral imports into the United States indicate future opportunities for ecosystem and societal benefits. Conserv. Lett., 5, 478-485 (2012).

Rosa, R., S. Morais, R. Calado, L. Narciso and M.L. Nunes: Biochemical changes during the embryonic development of Norway lobster, Nephrops norvegicus (crustacea: decapoda). Aquacult., 221, 507$522(2003)$.

Sargent, J. R.: Origins and functions of egg lipids: nutritional implications.
In: Broodstock management and egg and larval quality (Eds.: N.R. Bromage and R.J. Roberts) Blackwell Science, pp. 353-372 (1995).

Saritha, K., D. Mary and J. Patterson: Nutritional status of green mussel Perna viridis at Tamil Nadu, south-west coast of India. J. Nutr. Food Sci., S14, 1-4 (2015).

Simoes, F., F. Ribeiro, and D.A. Jones: The effect of diet on the reproductive performance of marine cleaner shrimps $L$. debelius (Bruce, 1983) and Lysmata amboinensis (de Man, 1888) (Caridea, Hippolytidae) in captivity. Aquaculture 98 Book of Abstracts, Las Vegas, Nevada, USA (1998).

Suprayudi, M.A., T. Takeuchi and K. Hamasaki: Essential fatty acids for larval mud crab Scylla serrata: implications of lack of the ability to bioconvert $\mathrm{C} 18$ unsaturated fatty acids to highly unsaturated fatty acids. Aquacult., 231, 403-416 (2004).

Takeuchi, T., N. Satoh, S. Sekiya, T. Shimizu and T. Watanabe: The effect of dietary EPA and DHA on molting rate of larval swimming crab Portunus trituberculatus. Nippon Suisan Gakk., 65, 988-1004 (1999).

Thornhill, D.J.: Ecological Impacts and Practices of the Coral Reef Wildlife Trade. Washington: Defenders of Wildlife (2012).

Tziouveli, V.: Broodstock conditioning and larval rearing of the marine ornamental white-striped cleaner shrimp, Lysmata amboinensis (de Man, 1888). (PhD thesis). James Cook University, Australia (2011).

Tziouveli, V., M. Hall and G. Smith: The effect of maturation diets on the reproductive output of the white-striped cleaner shrimp, Lysmata amboinensis. J. World Aquacult. Soc., 42, 56-65 (2011).

Tziouveli, V., M. Hall and G.G. Smith: Evaluation of lipid-enriched Artemia on the reproductive performance of the white-striped cleaner shrimp, Lysmata amboinensis. Aquac. Int., 20, 201-211 (2012).

Wen, X.B., L.Q. Chen, Z.L. Zhou, C.X. Ai and G.Y. Deng: Reproduction response of Chinese mittenhanded crab (Eriocheir sinensis) fed different source of dietary lipid. Comp. Biochem. Phys. A:131,675$681(2002)$

Williams, K.C.: Nutritional requirements and feeds development for postlarval spiny lobster: Areview. Aquac., 263, 1-14 (2007).

Xu , X.L., W.J. Ji, J.D. Castell and R.K. O'Dor: Essential fatty acid requirement of the Chinese prawn Penaeus chinensis. Aquac., $127,29-40$ (1994). 